\title{
Observations of meteorological tsunamis along the south-west Australian coast
}

\author{
Charitha Pattiaratchi • E. M. S. Wijeratne
}

Received: 2 September 2013/ Accepted: 26 May 2014/Published online: 6 June 2014

(C) The Author(s) 2014. This article is published with open access at Springerlink.com

\begin{abstract}
Tide gauge data were used to identify the occurrence, characteristics, and cause of tsunamis of meteorological origin (termed 'meteotsunamis') along the Western Australian coast. This is the first study to identify meteotsunamis in this region, and the results indicated that they occur frequently. Although meteotsunamis are not catastrophic to the extent of major seismically induced basin-scale events, the wave heights of meteotsunamis examined at some local stations in this study were higher than those recorded through seismic tsunamis. In June 2012, a meteotsunami contributed to an extreme water-level event at Fremantle, which recorded the highest water level in over 115 years. Meteotsunamis (wave heights $>0.4 \mathrm{~m}$, when the mean tidal range in the region is $\sim 0.5 \mathrm{~m}$ ) were found to coincide with thunderstorms in summer and the passage of low-pressure systems during winter. Spectral analysis of tide gauge time series records showed that existing continental seiche oscillations (periods between $30 \mathrm{~min}$ and $5 \mathrm{~h}$ ) were enhanced during the meteotsunamis, with a high proportion of energy transferred to the continental shelf oscillation period. Three recent meteotsunami events (22 March 2010, 10 June 2012, and 7 January 2013) two due to summer thunderstorms and one due to a winter frontal system were chosen for detailed analysis. The meteotsunami amplitudes were up to a factor 2 larger than the local tidal range and sometimes contributed up to $85 \%$ of the non-tidal water signal. A single meteorological event was found to generate several meteotsunamis along the coast, up to $500 \mathrm{~km}$ apart, as the air pressure disturbance propagated over the continental shelf; however, the topography and local bathymetry of the continental shelf defined the local sea-level resonance characteristics at each location. With the available data (sea level and meteorological), the exact mechanisms for the generation of the meteotsunamis could not be isolated.
\end{abstract}

Keywords Meteotsunamis $\cdot$ Thunderstorms $\cdot$ Proudman resonance $\cdot$ South-west Australia

C. Pattiaratchi $(\varangle) \cdot$ E. M. S. Wijeratne

School of Civil, Environmental and Mining Engineering, The UWA Oceans Institute, The University of Western Australia, 35 Stirling Highway, Crawley 6009, Australia

e-mail: chari.pattiaratchi@uwa.edu.au 


\section{Introduction}

Meteorological tsunamis, or meteotsunamis, are similar to tsunami waves (defined as long or shallow-water waves, where the wave length, $\mathrm{L}$, is much greater than the water depth, $\mathrm{h}$ ) that are generated by seismic activity, except they have a meteorological origin (Rabinovich and Monserrat 1998; Rabinovich 2009; Rabinovich et al. 2009; Pasquet et al. 2013). Meteotsunamis also have similar periods to seismic tsunamis (Monserrat et al. 2006). Meteorological disturbances, such as squalls, tornadoes, thunderstorms, frontal passages, and atmospheric gravity waves, can produce these longer-period surface waves, either locally or remotely. The main forcing mechanism of a meteotsunami is the propagation of an abrupt change in sea surface atmospheric pressure and/or associated wind gusts. Meteotsunamis have several local names such as rissaga in Spain's Balearic Islands (Monserrat et al. 1991; Vilibić et al. 2008) and around New Zealand (Heath 1982); abiki in Japan's Nagasaki Bay (Hibiya and Kajiura 1982); ščiga" in the Adriatic (e.g. Orlić et al. 2010); milghuba in Malta (Drago 2008); marrobbio ('mad sea') in Sicily (Candela et al. 1999); and seebär in the Baltic Sea (Defant 1961). Monserrat et al. (2006) described several large meteotsunamis, which occurred worldwide, and their generating mechanisms in their study on meteotsunamis.

Several resonance phenomena cause meteotsunamis: (a) Proudman resonance; (b) Greenspan resonance; and (c) continental shelf resonance. Proudman resonance (Proudman 1929; Vilibić 2008) describes the generation mechanism of meteotsunamis due to moving atmospheric disturbances when the speed of a moving atmospheric disturbance $(v)$ is close to the shallow-water wave celerity c $(c=\sqrt{g h})$. Here, the barotropic long wave generated by the propagating pressure signal is amplified at the coast. It has often been suggested to be the main cause of meteotsunamis occurring worldwide, for example, in Ciutadella Harbour, Balearic Islands (Gomis et al. 1993; Garcies et al. 1996; Monserrat et al. 2006); in Nagasaki Bay, Japan (Hibiya and Kajiura 1982); along the Croatian coast in the Adriatic Sea (Orlić 1980); in southern United Kingdom (Haslett and Bryant 2009; Tappin et al. 2013); and off the west coast of Korea (Cho et al. 2013).

Greenspan (1956) described the amplification of the resonance oscillation when the alongshore component of the atmospheric disturbance speed is the same as the phase speed of the edge waves. When the natural oscillating period of a continental shelf is equal to the periods contained in a meteotsunami, shelf resonance similar to that experienced with seismic tsunamis occurs (Rabinovich 2009; Pattiaratchi and Wijeratne 2009; Wijeratne et al. 2010). When the different resonance processes (Proudman and/or Greenspan, and shelf) combine, larger meteotsunamis can result at the coast (Vilibić and Šepić 2009).

In some areas, meteotsunamis occur regularly over seasons or years because of the quasi-cyclical characteristics of their forcing mechanisms. Based on meteotsunami statistics from Ciutadella inlet, in the Balearic Islands, Rabinovich (2009) showed that meteotsunamis with amplitudes higher than $0.2 \mathrm{~m}, 0.5 \mathrm{~m}$, and 3-4 m ('rissaga' events) occurred every summer, once every 5-6 years, and once every 15-20 years, respectively. Since 1984, the Spanish National Institute of Meteorology has been using weather predictions and numerical simulations to forecast meteotsunamis (Jansa et al. 2007; Renault et al. 2011).

This study investigated meteotsunamis along the south-west coast of Western Australia (WA). Tide gauge records were used to study water-level oscillations with periods $<6 \mathrm{~h}$, which were then related to local atmospheric data. Spectral analyses of tide gauge records were undertaken to examine the meteotsunami oscillation characteristics of the region. 
This paper is arranged as follows: Sect. 2 describes the oceanographic and meteorological characteristics of the study area. Data analysis techniques are outlined in Sect. 3, and meteotsunami data obtained from the tide gauge records and the associated meteorological data are presented in Sect. 4. The results are discussed in Sect. 5, and the conclusions are presented in Sect. 6.

\section{Study area}

The study area was the south-west coast of Australia between Esperance and Carnarvon (Fig. 1). This region mainly experiences diurnal, microtidal conditions, and has a mean tidal range of $\sim 0.5-0.8 \mathrm{~m}$ (Pattiaratchi and Eliot 2009; Pattiaratchi 2011). It also experiences a sea-level variability of $\sim 0.20 \mathrm{~m}$ at different timescales from nodal tides (18.6year cycle), seasonal tides, inter-annual tides, and continental shelf seiches $(\sim 2-4 \mathrm{~h})$. The region's small water-level range means that even a small meteotsunami or seiche

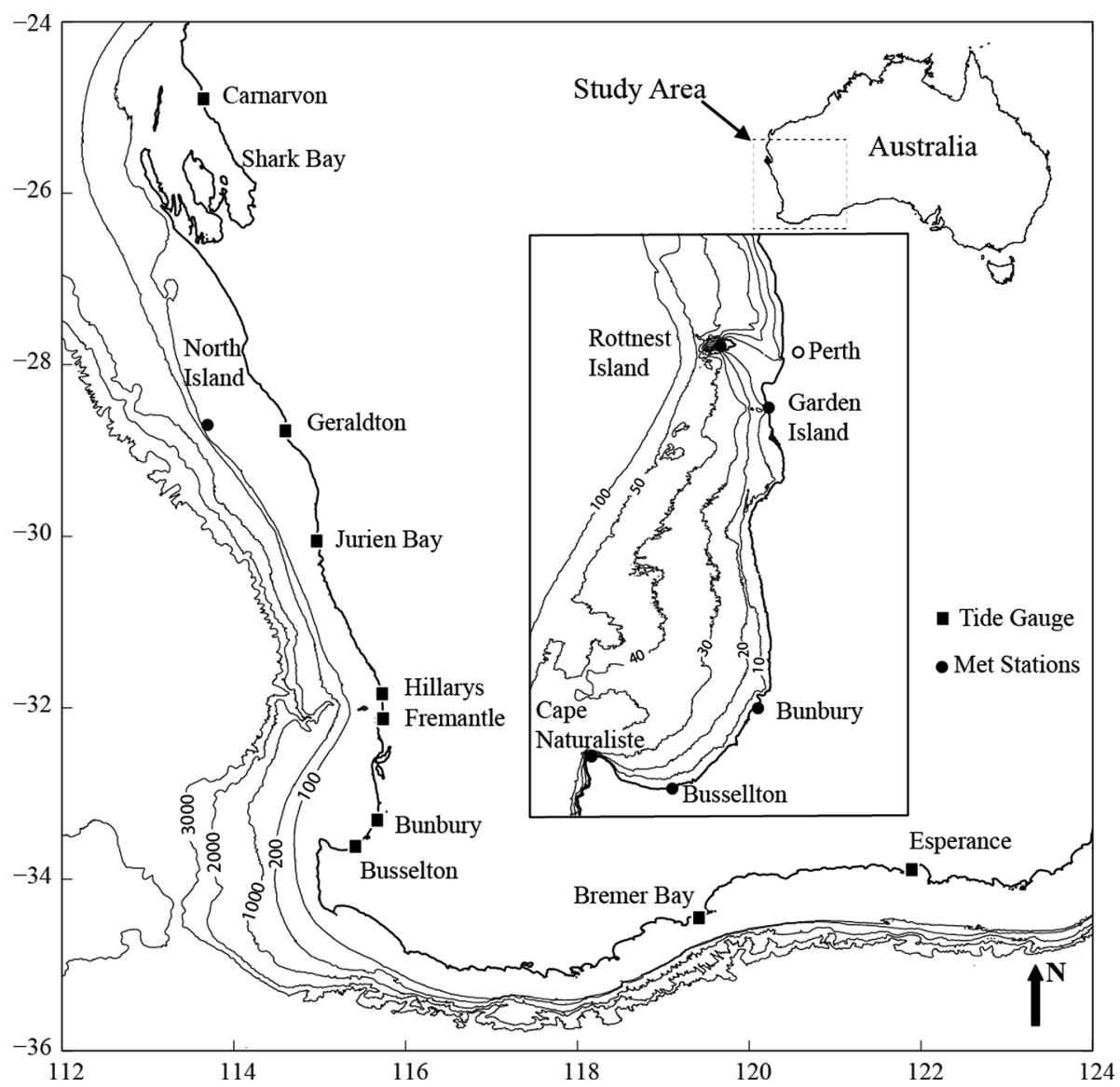

Fig. 1 Map showing the study region, bathymetry $(\mathrm{m})$, tide gauge, and meteorological station locations. The black rectangles (filled square) denote the tide gauge locations; the black circles (filled circle) denote meteorology stations. Inset shows a higher resolution of the south-west region with meteorological stations 
$(\sim 0.25 \mathrm{~m})$ amounts to a large proportion of the local tidal range. Extra-tropical storms cause most of the storm surge events, which have magnitudes of up to $1 \mathrm{~m}$; however, surges of up to $1.5 \mathrm{~m}$ have been recorded when tropical cyclones track south over the region (Haigh et al. 2014).

Australia's west coast is also exposed to seismic tsunamis originating from the Java trench. The highest tsunami wave height $(1.75 \mathrm{~m})$ recorded on the WA coast was at Bunbury on 26 December 2004 (Table 1). Since December 2004, tide gauges along the WA coast have recorded several seismic tsunami-induced waves, but maximum wave heights have not exceeded $1 \mathrm{~m}$ (Pattiaratchi and Wijeratne 2009).

The region experiences several meteotsunami-generating mechanisms, such as squalls, tornadoes, thunderstorms, and frontal passages, which are generally confined to certain regions or seasons. Pressure perturbations, within an extent of a thunderstorm, are such that downdrafts are ushering colder air from mid-levels hitting ground and propagating away in all directions, a high-pressure jump is to be found widely at surface levels, usually indicative of strong (potentially damaging) winds. In winter, the region is subject to the passage of frontal systems, which produce strong north-westerly winds $\left(25-30 \mathrm{~ms}^{-1}\right)$. These winds change direction to the west then south-west over 12-16 h, then weaken over 2-3 days, which allows swell-dominated conditions to prevail for another three to 5 days before another frontal system passes. Up to 30 such storm systems are experienced each year (Verspecht and Pattiaratchi 2010).

Table 1 Maximum meteotsunami and seismic wave heights (derived from 2004 to 2005 Indian Ocean tsunamis) obtained with the tide gauges

\begin{tabular}{|c|c|c|c|c|}
\hline Station & Date & $\begin{array}{l}\text { Maximum } \\
\text { meteotsunami } \\
\text { wave height } \\
\text { (trough to crest) }\end{array}$ & $\begin{array}{l}\text { Maximum } 2004 \\
\text { seismic-tsunami } \\
\text { wave height } \\
\text { (trough to crest)* }\end{array}$ & $\begin{array}{l}\text { Maximum } 2005 \\
\text { seismic-tsunami wave } \\
\text { height (trough to crest)* }\end{array}$ \\
\hline Carnarvon & 23 October 2006 & $0.60 \mathrm{~m}$ & $1.14 \mathrm{~m}$ & $0.30 \mathrm{~m}$ \\
\hline Geraldton & $\begin{array}{l}25 \text { February } 2005 \\
07 \text { January } 2013\end{array}$ & $\begin{array}{l}0.42 \mathrm{~m} \\
0.82 \mathrm{~m}\end{array}$ & $1.65 \mathrm{~m}$ & $0.40 \mathrm{~m}$ \\
\hline Jurien Bay & 07 January 2013 & $0.43 \mathrm{~m}$ & $0.90 \mathrm{~m}$ & $0.38 \mathrm{~m}$ \\
\hline Fremantle & $\begin{array}{l}17 \text { October } 2002 \\
22 \text { March } 2010 \\
\text { 10 June } 2012 \\
\text { 07 January } 2013\end{array}$ & $\begin{array}{l}0.72 \mathrm{~m} \\
0.55 \mathrm{~m} \\
0.61 \mathrm{~m} \\
0.48 \mathrm{~m}\end{array}$ & $0.60 \mathrm{~m}$ & 0.32 \\
\hline Bunbury & $\begin{array}{l}\text { 05 December } 2002 \\
22 \text { March } 2010 \\
\text { 10 June } 2012 \\
\text { 07 January } 2013\end{array}$ & $\begin{array}{l}0.90 \mathrm{~m} \\
0.40 \mathrm{~m} \\
1.03 \mathrm{~m} \\
0.30 \mathrm{~m}\end{array}$ & $1.75 \mathrm{~m}$ & $0.49 \mathrm{~m}$ \\
\hline Busselton & $\begin{array}{l}22 \text { March } 2010 \\
10 \text { June } 2012 \\
07 \text { January } 2013\end{array}$ & $\begin{array}{l}0.45 \mathrm{~m} \\
1.10 \mathrm{~m} \\
0.40 \mathrm{~m}\end{array}$ & 1.15 & $0.49 \mathrm{~m}$ \\
\hline $\begin{array}{l}\text { Bremer } \\
\text { Bay }\end{array}$ & 28 November 2006 & $0.61 \mathrm{~m}$ & - & - \\
\hline Esperance & $\begin{array}{l}28 \text { November } 2006 \\
\text { 08 January } 2008\end{array}$ & $\begin{array}{l}0.60 \mathrm{~m} \\
0.70 \mathrm{~m}\end{array}$ & 0.44 & $0.11 \mathrm{~m}$ \\
\hline
\end{tabular}

* From Pattiaratchi and Wijeratne (2009) 
Thunderstorms mainly occur in the warmer seasons, from October to April, and usually in the afternoon when surface heating is high (Kuleshov et al. 2002); however, uplift forced by strong easterly winds near the surface can also cause early morning thunderstorms. Courtney and Middelmann (2005) showed that the number of warm-season thunderstorm days varied from year to year, with a mean occurrence of five to six thunderstorms a year.

Most thunderstorms are localised in contrast to tropical cyclones and winter fronts, which extend over large areas. Individual thunderstorms typically extend over an area less than $10 \mathrm{~km}^{2}$, move at 6-11 $\mathrm{ms}^{-1}\left(20-40 \mathrm{~km} \mathrm{~h}^{-1}\right)$, and last only a few hours; however, multiple thunderstorm cells typically form in any given event, so the overall affected area may be greater. Prolonged thunderstorms, called 'supercells', can produce large hail, strong wind gusts, powerful tornadoes, and heavy rainfall as occurred in Perth on 22 March 2010, (Bureau of Meteorology 2012).

The width of the continental shelf in the study region varies from $25 \mathrm{~km}$ (off Jurien Bay, Fig. 1) to $80 \mathrm{~km}$ (off Carnarvon, Geraldton, Bunbury, Esperance; Fig. 1). The mean shelf depth is $\sim 50 \mathrm{~m}$. Merian's formula for an open system (Pugh 1987) can be used to estimate continental shelf seiche oscillation periods:

$$
T=\frac{1}{n} \frac{4 L}{\sqrt{g h}}
$$

where $T$ is the continental shelf seiche period; $L$ is the shelf width; $h$ is the mean shelf water depth; $g$ is acceleration due to gravity; and $n$ is the mode number, with $n=1$ being the fundamental mode. Thus, the fundamental mode of the continental shelf seiche period along the south-west coast varies between $\sim 2.7$ to $4 \mathrm{~h}$ (see also Pattiaratchi and Wijeratne 2009).

Bay and harbour oscillations can also cause seiche oscillations with other periods along the coast. Seiches have often been observed along the south-west WA coast. Ilich (2006) found changes in the wind direction generated these seiches. Strong harbour seiches (with periods $<5 \mathrm{~min}$ ) have also been observed in many WA ports and marinas, such as Two Rocks (Thotagamuwage and Pattiaratchi 2011), and can affect ship manoeuvring and anchoring.

\section{Data analysis}

Time series records from eight tide gauge stations, Carnarvon, Geraldton, Jurien Bay, Fremantle, Bunbury, Busselton, Bremer Bay, and Esperance, located along the south-west Australian coast (Fig. 1) were obtained from the Department of Transport. We focused our analysis on the records obtained since the year 2000, when high-frequency data (sampling periods between 1 and $5 \mathrm{~min}$ ) were available. The water-level time series records were subjected to several filtering methods to isolate the meteotsunami signal (see Fig. 2, which shows the results obtained from Fremantle in January 2013):

(a) The observed water-level record (Fig. 2a) was subjected to harmonic analysis using the T-Tide MATLAB toolbox (Pawlowicz et al. 2002) to remove the tidal components (Fig. 2b) from the sea-level records, resulting in the residual time series shown in Fig. 2c.

(b) The residual time series (Fig. 2c) was subjected to a low-pass filter to remove the periods $<36 \mathrm{~h}$, resulting in a time series that included the storm surge and weather band frequencies (Fig. 2d).

(c) The storm surge and weather band frequencies (Fig. 2d) were subtracted from the residual time series (Fig. 2c) to provide a time series that contained periods $<\sim 6 \mathrm{~h}$, which included seiches and tsunami waves (both seismic and meteo). 

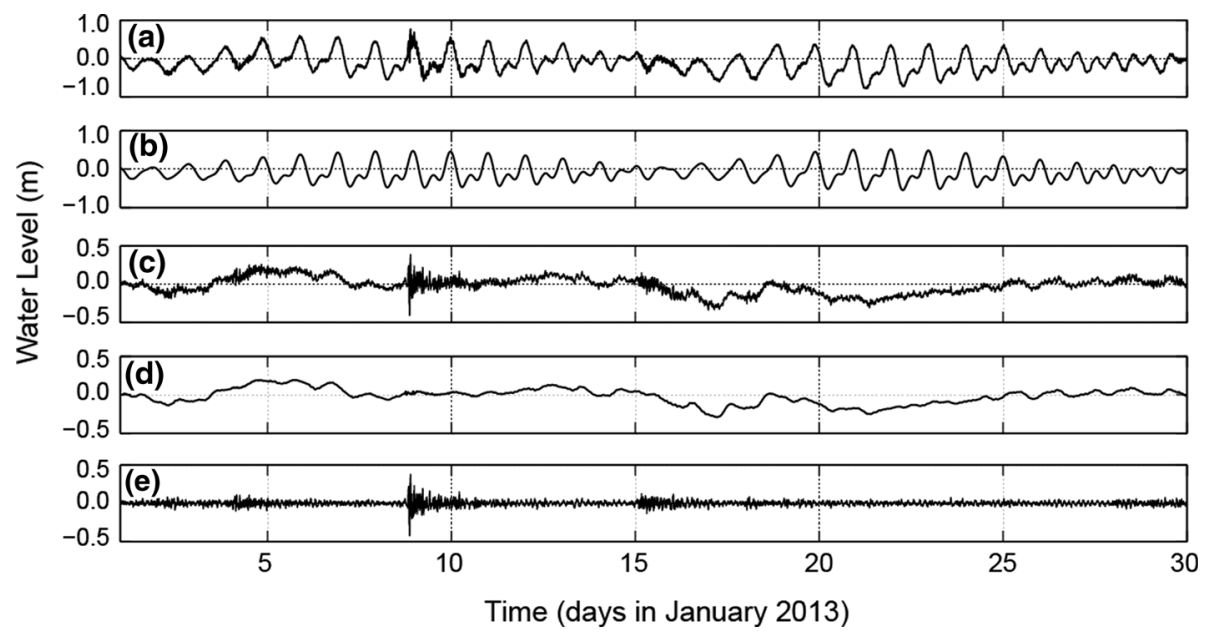

Fig. 2 Time series of the Fremantle sea-level record for January 2013 showing the filtering procedure used to isolate the meteotsunamis with periods $<6 \mathrm{~h}$ : a the observed water-level time series; b the tidal component time series from the harmonic analysis; c the residual time series: observed record (a) tidal component (b); d low-pass-filtered time series; and e time series with periods $<6 \mathrm{~h}$ to identify tsunami waves (both seismic and meteo): series(c)-series(d)

Tide gauges were located inside harbours or large bays; thus, we expected different seiche frequencies to be present in the records because of the combination of basin, harbour, and continental shelf oscillations (Ilich 2006). To identify the dominant frequencies present in the sea-level time series records, Fourier and Wavelet transforms were used. Fourier transforms were used to construct time-frequency plots from the autospectra and were used to identify the temporal changes in the spectral energy distribution. Fast Fourier transform, Welch's method, and a time series of 2048 points were used to estimate the power spectra (see also Pattiaratchi and Wijeratne 2009). A $50 \%$ overlap (i.e. 1,024 points) was used to calculate subsequent autospectra. Wavelet transforms are used to analyse time series that contain non-stationary power at many different frequencies (Torrence and Compo 1998). Wavelet analysis maintains time and frequency localisation in a signal analysis by decomposing or transforming a one-dimensional time series into a diffuse two-dimensional time-frequency image simultaneously. The recorded time series and/or the residual time series were decomposed using Torrence and Compo's (1998) continuous wavelet method.

Meteorological data and extreme weather records for the past 10 years were obtained from the Bureau of Meteorology. The high-frequency (1-30 min) time series of air pressure and wind data was obtained from six meteorological observation sites (Fig. 1) and was related to the observed water-level changes. We used Orlić's (1980) geometric expression to determine the air pressure disturbance's travelling speed $(v)$ and direction $(\gamma)$ over the shelf (see also Garcies et al. 1996; Šepić et al. 2009; Nudelman et al. 2010):

$$
f(v, \gamma)=\sum_{i=1}^{n}\left(\Delta t_{i}-\overline{\Delta t_{i}}\right)^{2}=\sum_{i=1}^{n}\left(\frac{\delta_{i} \cdot \cos \left(\gamma_{i}, \gamma\right)}{v}-\overline{\Delta t_{i}}\right)^{2}
$$

where $\Delta t$ is the difference in the start time of the pressure change between meteorological stations, and $\delta$ is the distance between corresponding stations. 


\section{Results}

\subsection{Observations of meteotsunamis at different locations}

We identified several meteotsunamis with different magnitudes from the tide gauge records (Fig. 1). Here, the focus is on describing the characteristics (heights, period) of the largest meteotsunami events (crest-to-trough wave height $>0.40 \mathrm{~m}$ ) at each location and their relation to the local meteorological conditions between January 2000 and January 2013 (Table 1). The results from six stations along south-west coastline are shown in Fig. 3 (see also Table 1) and presented below. The Bureau of Meteorology weather records were used to identify the atmospheric conditions present at the time of each meteotsunami, and detailed analyses using meteorological stations data during selected events are presented in Sect. 4.2. Time-frequency spectral plots of the sea-level records obtained during the meteotsunamis are also presented to examine the wave periods in the record.

\subsubsection{Carnarvon: 23 October 2006}

Thunderstorms with widespread wind gusts of $90-100 \mathrm{~km} \mathrm{~h}^{-1}$ were reported in WA's central coastal region in the early morning of 23 October 2006. These thunderstorms produced a meteotsunami, whose oscillations were recorded on tide gauges at Carnarvon and Geraldton (Fig. 1). A maximum wave height of $0.60 \mathrm{~m}$ was recorded at Carnarvon (Fig. 3a), and the resulting high-frequency oscillations continued for $\sim 8 \mathrm{~h}$. The existing seiche oscillations were excited at $\sim 0300$, but the highest wave (crest-to-trough height) occurred at $\sim 0800$, which corresponded to low tide. Carnarvon experiences mixed tidal conditions and a spring tidal range of $\sim 3 \mathrm{~m}$ (Burling et al. 2003). Meteotsunami-like events were not observed at tide stations farther north, where spring tidal ranges are between 3 and $10 \mathrm{~m}$. The highest wave height recorded at Carnarvon for the 26 December 2004 tsunami was $1.14 \mathrm{~m}$, whereas for the 28 March 2005 tsunami, it was only $0.3 \mathrm{~m}$ (Pattiaratchi and Wijeratne 2009).

The energy spectra for Carnarvon for 20-28 October 2006 showed the meteotsunami of 23 October enhanced the energy at 30- and 80-min periods (Fig. 3g). Both the 30- and 80 -min periods could be related to bay oscillation. The shelf is wide $(>80 \mathrm{~km})$ at Carnarvon; thus, we expected the fundamental shelf oscillation to be longer than $4 \mathrm{~h}$; however, oscillation periods with this range were absent from the energy spectra.

\subsubsection{Geraldton: 25 February 2005}

At $\sim 0400$ on 25 February 2005, a meteotsunami with a maximum wave height of $0.42 \mathrm{~m}$ was recorded at Geraldton (Fig. 3b). Tide gauges at Carnarvon and Jurien Bay also recorded meteotsunamis with small wave heights $(<0.4 \mathrm{~m})$ the same day; however, no extreme meteorological events in these regions were reported. The energy spectra for Geraldton for 22 February-2 March 2005 showed enhanced spectral energy at the 35-, 80-min, and 4-h periods, which was associated with the 25 February meteotsunami (Fig. 3h). The 80-min period might have been related to the first mode $(n=2)$ of shelf resonance periods, and the 4-h period was related to the fundamental $(n=1)$ shelf resonance period with a shelf width of $80 \mathrm{~km}$ (Eq. 1). This 4-h period was also excited during seismic tsunamis at this location (Pattiaratchi and Wijeratne 2009). The meteotsunami caused the energy bands at all frequencies to increase at the same time, with the strongest 
(a)

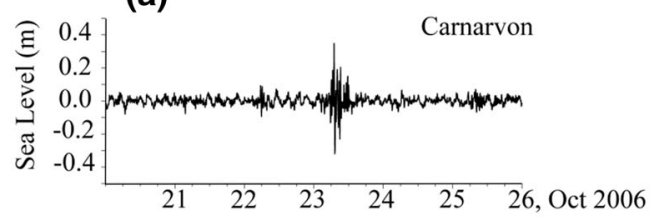

(b)

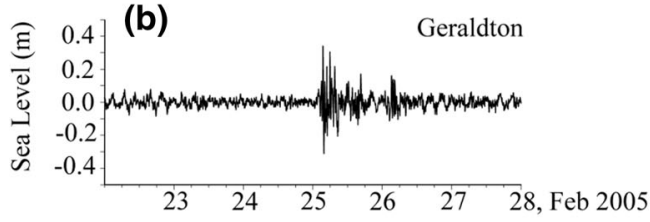

(c)

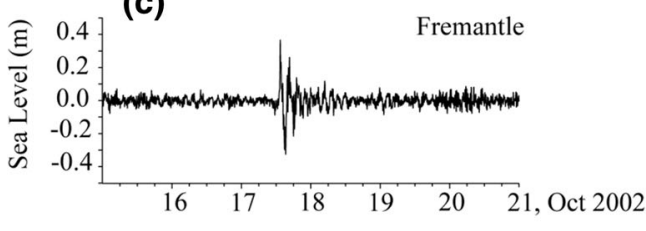

(d)

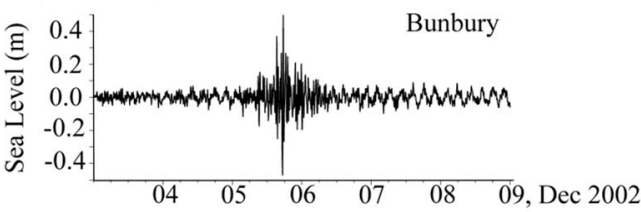

(e)
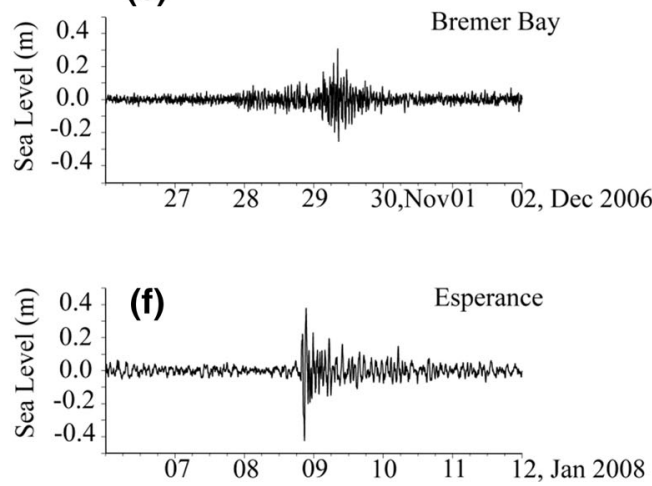
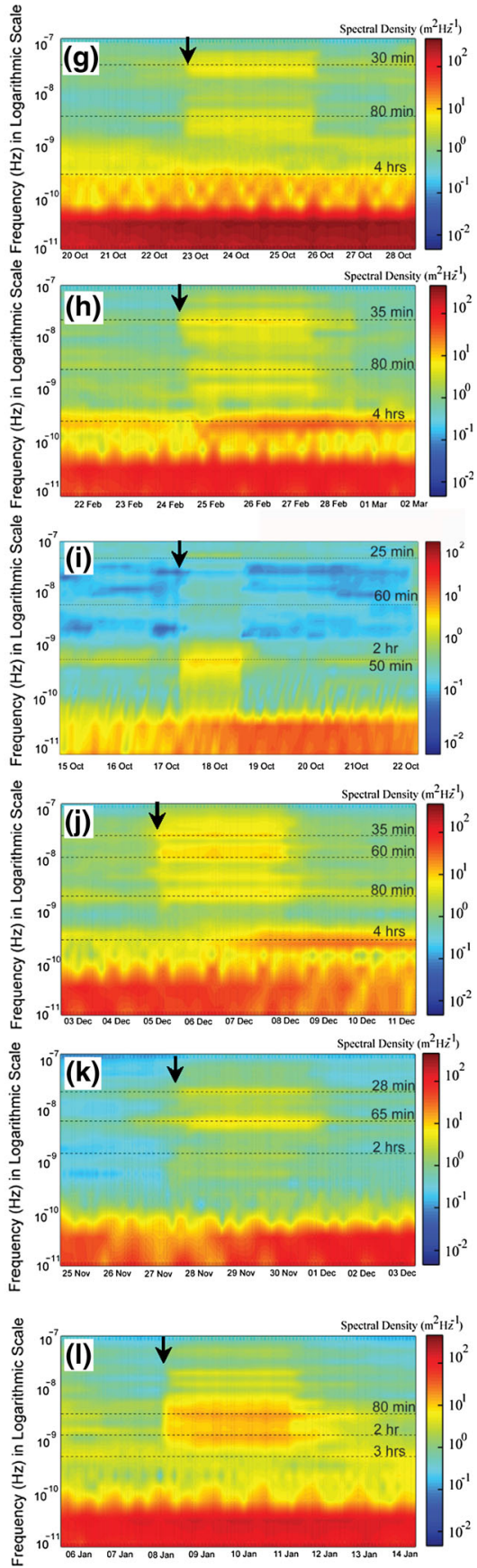

Fig. 3 a-f Time series of select large meteotsunamis recorded at different sites along the south-west coast of Western Australia between 2002 and 2008; g-l the corresponding spectral energy distribution timefrequency plots using Fourier analysis. The start of the meteotsunami is shown on the spectral plots $\mathbf{g}-\mathbf{l}$ with a vertical arrow 

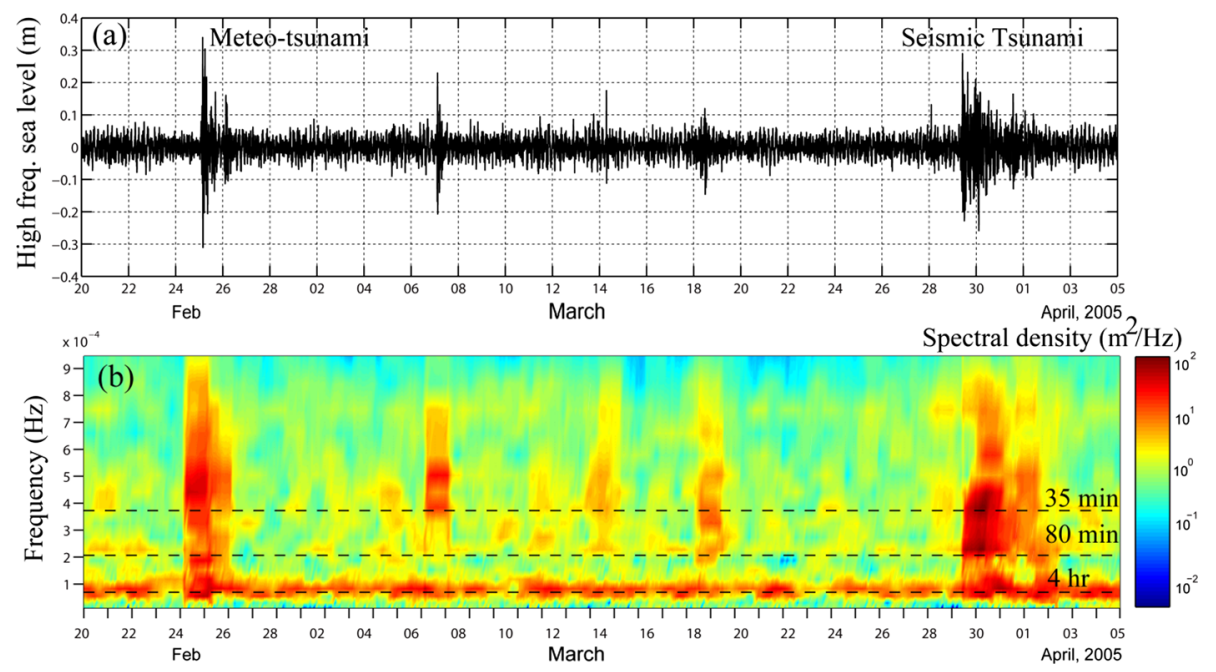

Fig. 4 Time series of the meteotsunami and seismic tsunamis at Geraldton from 20 February to 5 April 2005. a Tsunami-induced sea-level oscillations; b the spectral energy distribution over the time and frequency axis

energy occurring during the 4-h period. A filtered time series and time-spectral plot of the seismic and meteorological tsunamis that occurred at Geraldton between February and April 2005 (Fig. 4) also showed that the seismic and meteorological tsunamis had enhanced existing seiche frequency-band oscillations. In contrast, the larger-amplitude shelf oscillations at the 4-h period were present almost continuously.

\subsubsection{Fremantle: 17 October 2002}

A strong cold front hits the south-west of WA at $\sim 1300$ on 17 October 2002. Several tornadoes that occurred at different sites in the study region were associated with this front. Four tornadoes were reported in the Perth metropolitan area (Courtney and Middelmann 2005). Meteorologically induced sea-level oscillations were recorded at several tide stations along the west and south coasts. At $\sim 1330$ on 17 October, the Fremantle tide gauge recorded a meteotsunami (Fig. 3c). The initial wave height (crest to trough) recorded at Fremantle was $\sim 0.7 \mathrm{~m}$, which was double the tsunami wave height of $0.33 \mathrm{~m}$ recorded at Fremantle as a result of the seismic tsunami of 26 December 2004 (Pattiaratchi and Wijeratne 2009).

The spectral analysis results of the energy distribution from the tide gauge records from 15 to 22 October 2002 are shown in Fig. 3i. The spectral energy bands show waves with periods of $25 \mathrm{~min}, 1$, and $2 \mathrm{~h}$ and $50 \mathrm{~min}$. The spectral analysis results showed the meteotsunami enhanced the existing seiche energy, with the strongest energy occurring during the $2 \mathrm{~h}$ and 50-min period; this period was related to the shelf resonance (see Pattiaratchi and Wijeratne 2009; Pattiaratchi 2011).

\subsubsection{Bunbury: 5 December 2002}

At $\sim 1700$ on 5 December 2002, a thunderstorm and associated large hail occurred in the south-west of WA. The resulting meteotsunami was recorded at the Bunbury, Busselton, 
and Hillarys Harbour tide gauges. The meteotsunami-induced sea-level oscillations at Bunbury (Fig. 3d), which continued for more than a day, reached a maximum height (crest to trough) of $0.9 \mathrm{~m}$; however, this wave occurred several hours after the first meteotsunami oscillation. In comparison, the highest crest-to-trough wave height recorded at Bunbury during the December 2004 tsunami was $1.75 \mathrm{~m}$; this was also the highest recorded wave height along this part of the coast (Pattiaratchi and Wijeratne 2009).

The time-frequency plot for 3-11 December 2002, which includes the meteotsunami recorded at Bunbury, is shown in Fig. 3j. The four seiche frequency bands show waves with periods of $35,60,80 \mathrm{~min}$, and $4 \mathrm{~h}$, with the highest spectral energy occurring during the 4-h period and continuing past 11 December. In contrast to the meteotsunamis that occurred at Geraldton and Fremantle (see above), the energies in the lower period $(<80 \mathrm{~min})$ were enhanced at the start of the meteotsunami, but the shelf oscillations at the 4-h period did not increase until several hours later.

The Bunbury and Busselton tide gauges recorded the highest number of large meteotsunamis (wave heights larger than the mean tidal range of $0.5 \mathrm{~m}$ ) during the study period. Three recent events from this region were chosen for detailed analysis, and the results are presented in Sect. 4.2.

\subsubsection{Bremer Bay: 28 November 2006}

On 28 November 2006, strong winds and cold fronts were reported at Rottnest Island (Fig. 1). The south-west WA tide gauges recorded a meteotsunami on the same day. The tide gauges at Bunbury and Esperance (not shown here) recorded a meteotsunami with initial wave heights of $0.7 \mathrm{~m}$ (at $\sim 0230$ ) and $0.6 \mathrm{~m}$ (at $\sim 0320$ ), respectively. Meteotsunami-induced sea-level oscillations were also recorded at the inner Bremer Bay tide gauge, with a maximum height of $\sim 0.4 \mathrm{~m}$ recorded at $\sim 0700$ on 29 November (Fig. 3e).

The time series of spectral energy for the Bremer Bay meteotsunami on 29 November (Fig. 3k) showed the meteotsunami enhanced the frequency bands at the 28- and 65-min periods. These periods could be related to the fundamental and higher modes of the bay oscillation; however, the energy band of the shelf oscillation period could not be seen on the time-frequency plot.

\subsubsection{Esperance: 8 January 2008}

A severe thunderstorm with large hail and strong winds occurred in the south-west of WA in the late evening of 8 January 2008. This thunderstorm caused a meteotsunami along the south coast, which was recorded at the Esperance and Bremer Bay tide gauges. The meteotsunami occurred at Esperance at $\sim 1830$ and high-frequency oscillations continued for more than a day (Fig. 3f). The meteotsunami occurred during the rising mid-tide, and the first wave (with a height of $\sim 0.7 \mathrm{~m}$ ) was the largest in the wave group. For comparison, the highest wave recorded at Esperance on 26 December 2004 was $0.44 \mathrm{~m}$ (Pattiaratchi and Wijeratne 2009). The spectral energy distributions from the Esperance tide gauge records for 6-14 January 2008 are shown in Fig. 31. The figure shows the meteotsunami enhanced the energy at the 80 -min and 2-h periods.

One of the features of the time series of the meteotsunamis (Fig. 3) is such that at some locations, the first oscillation is the strongest whilst and at others the amplitude gradually increased and then decreased. Rabinovich and Monserrat (1996) classified these different types of oscillations as impulse (strong initial oscillation and fast decay), resonance (gradual build-up of oscillations), and complex (a mix of the two). The time series 
indicates that the meteotsunamis at Fremantle and Esperance were impulse whilst at the rest of the stations, it was resonance.

\subsection{Detailed analysis of meteotsunamis}

Detailed meteorological data (such as rainfall radar and sea surface pressure data, which define the propagation of thunderstorms) have been available since 2009. These data enabled us to examine three meteotsunami events (22 March 2010, 10 June 2012, and 7 January 2013) in more detail. These meteotsunamis were also recorded at more than one tide gauge station indicating the spatial extent of a single meteorological effect. For example, the meteotsunamis on 7 January 2013 (see below) were recorded in tide gages $>500 \mathrm{~km}$ apart.

\subsubsection{Meteotsunami: 22 March 2010}

The costliest natural disaster in Western Australian history, with a damage bill estimated at A $\$ 1.08$ billion, occurred in the Perth region between 15:30 and 17:00 on Monday 22 March 2010. Most of the damage was due to hail associated with thunderstorms, with coastal stations recording wind (gust) speed of more than $30 \mathrm{~ms}^{-1}$. The thunderstorms were initiated to the north of Perth and progressed south along the coast (shore parallel). Rottnest and Garden Island meteorological stations recorded a pressure change of $4 \mathrm{hPa}$ associated with the thunderstorms (Fig. 5a, b), which reduced to $2 \mathrm{hPa}$ as the storms progressed to Bunbury and Cape Naturaliste (Fig. 5c, d; locations in Fig. 1). The pressure jump was associated with changes in the wind speed and direction (Fig. 5), the period of pressure jump inconsistent from station to station. The timescale of the atmospheric
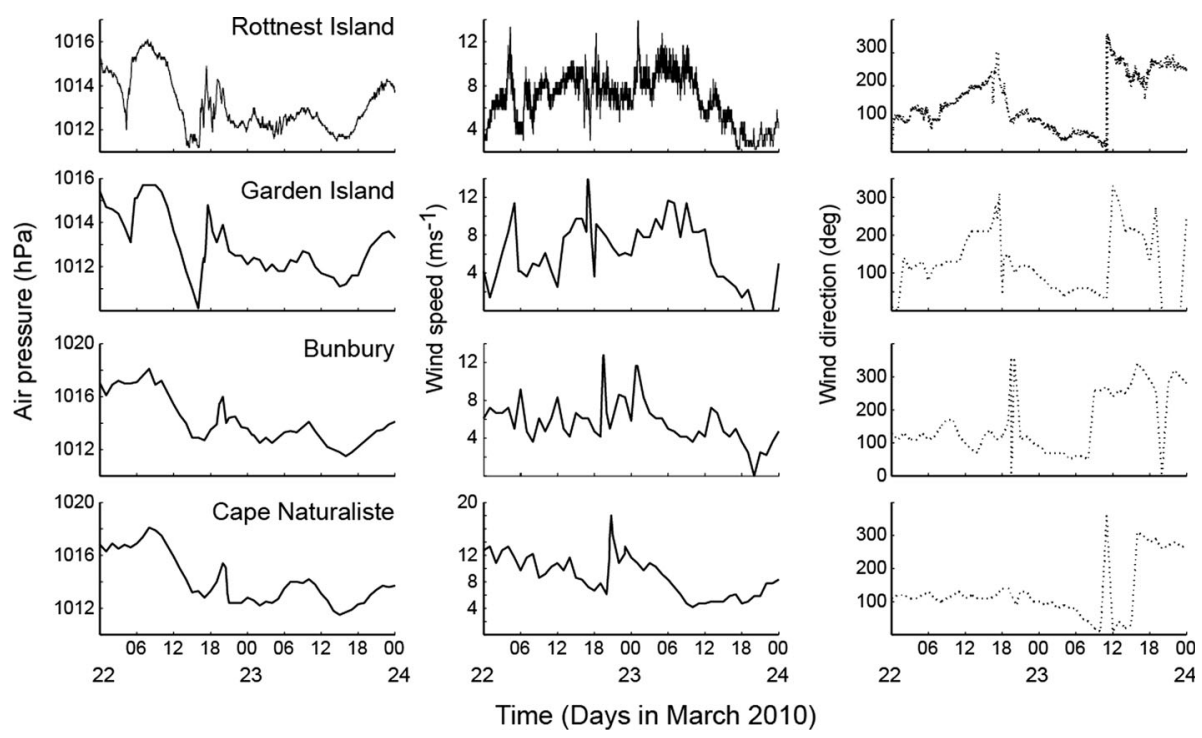

Fig. 5 Time series of air pressure (left panel); wind speed (middle panel); and wind direction (right panel) measured at meteorological stations along the Western Australian coast on 22 March 2010 showing the moving pressure jump and strong wind variability 
pressure change was 3.4 and $4 \mathrm{hPa}$ over $2 \mathrm{~h}$ at Rottnest Island and Garden Island, respectively (Fig. 5).

A time series of radar images of the rainfall (Fig. 6) shows the southward progression of the squall bands associated with the thunderstorms. Using Orlić (1980) formula (Eq. 2), including all meteorological stations, the average propagation speed of the pressure jump was $\sim 15 \mathrm{~ms}^{-1}$ and direction $\sim 002^{\circ}$ (meteorological convention). However, as to be expected, the propagation speed may have changed over the large area. The radar images indicated an alongshore propagation of the thunderstorms with a speed of $9.3 \mathrm{~ms}^{-1}$, which is equivalent to a shallow-water wave celerity in $8.8 \mathrm{~m}$ water depth, close to the shore (Fig. 1). In the region between Bunbury and Cape Naturaliste (Fig. 1), the pressure jump propagation speed increased to $18.9 \mathrm{~ms}^{-1}$ (based on Eq. 2) and the speed of the meteotsunami between Bunbury and Busselton (Fig. 7), based on the tide gauge data, was $17.5 \mathrm{~ms}^{-1}$. Both of these examples indicated that conditions were favourable for the occurrence of Proudman resonance. However, with the available data, it is not possible to
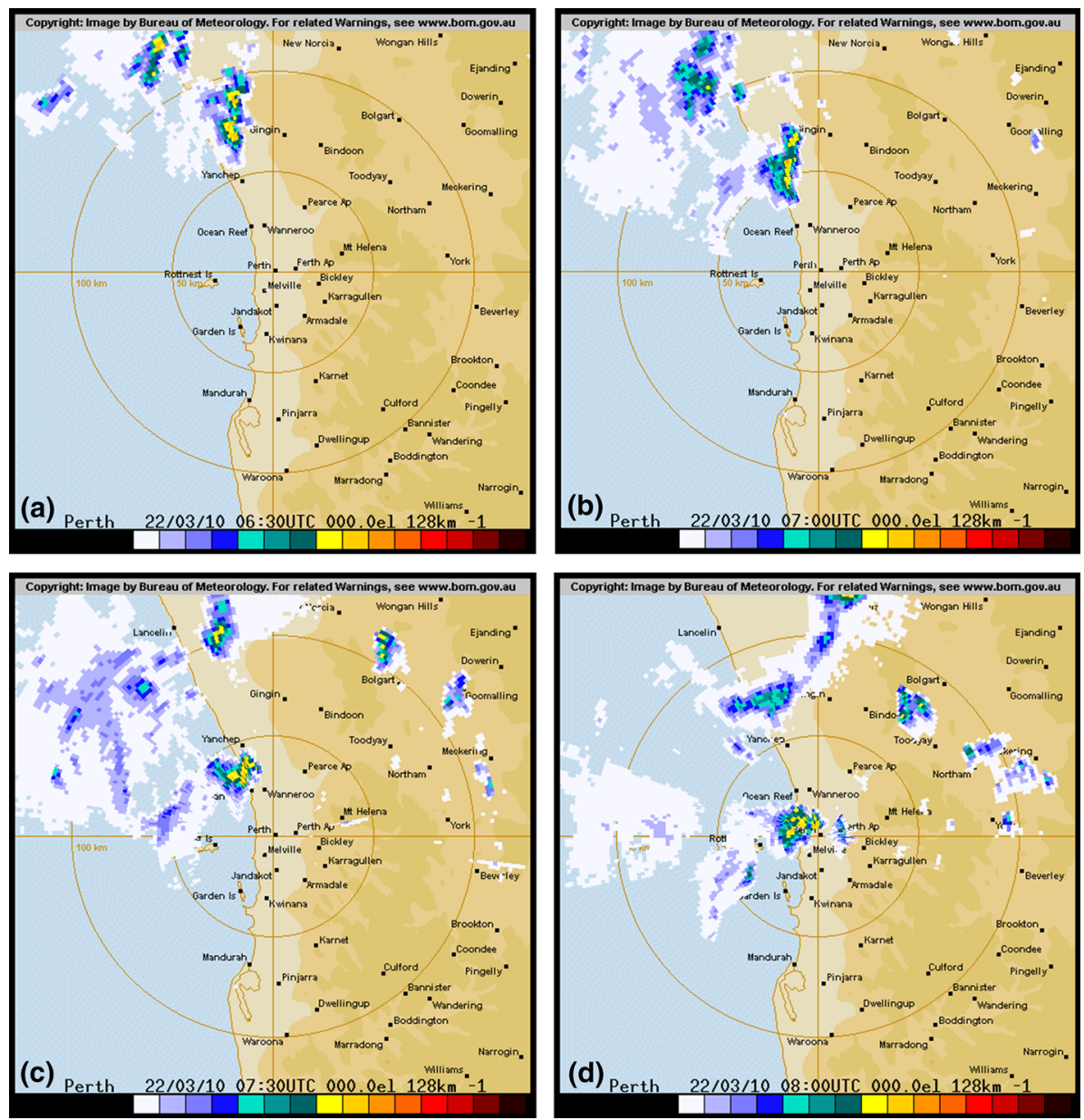

Fig. 6 Time series of radar rainfall images showing the passage of squall lines associated with thunderstorms on 22 March 2010 at a 1430 AWST; b 1500 AWST; c 1530 AWST; and d 1600 AWST. Warmer colours reflect higher rainfall rates. (image source: Bureau of Meteorology, Australia) 


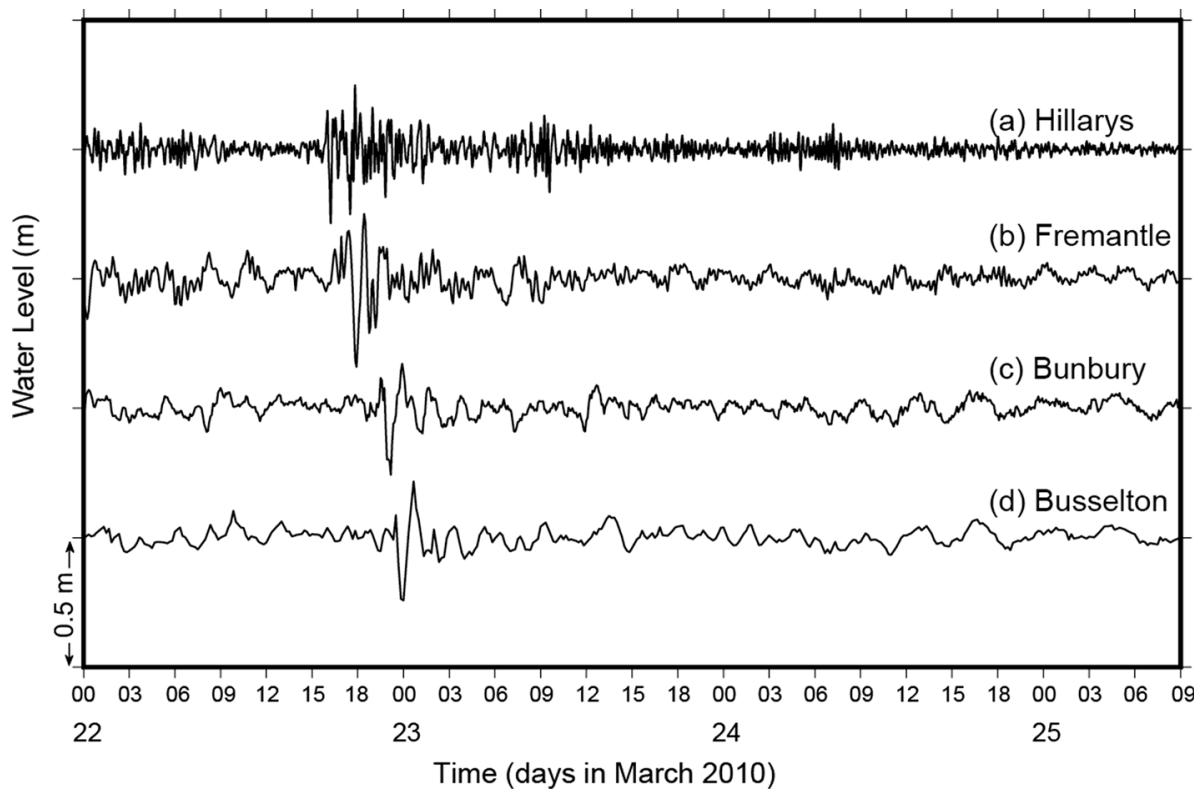

Fig. 7 Time series of filtered (periods $<6 \mathrm{~h}$ ) water-level records from 22-25 March 2010 for (a) Hillarys; (b) Fremantle; (c) Bunbury; and (d) Busselton

determine whether Proudman or Greenspan resonance was responsible for the generation of the meteotsunamis. The thunderstorms created a meteotsunami with maximum wave heights of 0.48, 0.55, 0.40, and $0.45 \mathrm{~m}$ at Hillarys, Fremantle, Bunbury, and Busselton, respectively (Fig. 7).

A wavelet transform of the Hillarys Boat Harbour sea-level (Fig. 1) record, which had a sampling interval of $6 \mathrm{~min}$ (Fig. 8), shows the water-level variability that occurred in the harbour. The wavelet transform also shows the presence of diurnal and semidiurnal energy and trophic/equatorial (O'Callaghan et al. 2010) and spring/neap tidal stages. The energy between the diurnal and semidiurnal components is separated because the record was obtained in March, close to the equinox when the tropic-equatorial and spring-neap tidal stages were out of phase (O'Callaghan et al. 2010). The water-level time series (Fig. 8a) shows the transformation of the tides from a diurnal to semidiurnal system and then back to a diurnal system. The time series also shows an energy peak of around $3 \mathrm{~h}$, which Pattiaratchi and Wijeratne (2009) identified as the first mode of the shelf resonance with a period of $2.7 \mathrm{~h}$ (Fig. 8b; see also Fig. 3c, i). During the meteotsunami, oscillations with periods of 1-2 h were strongly excited (Fig. 8d).

\subsubsection{Meteotsunami: 10 June 2012}

The meteotsunami recorded on 10 June 2012 was unusual in that it occurred during winter and was generated by the passage of a low-pressure system across south-west Australia (Fig. 9). The low-pressure system was initiated as a tropical low off WA's north-west coast, and moved almost parallel to the coast, with the centre of the low crossing the coast to the south of Perth (Bureau of Meteorology 2012). The system caused maximum (gust) wind speeds $>30 \mathrm{~ms}^{-1}$ and a rapid change in wind direction from shore parallel (northerly) to onshore (westerly) (Fig. 10). The system was extreme, with a drop in sea surface 

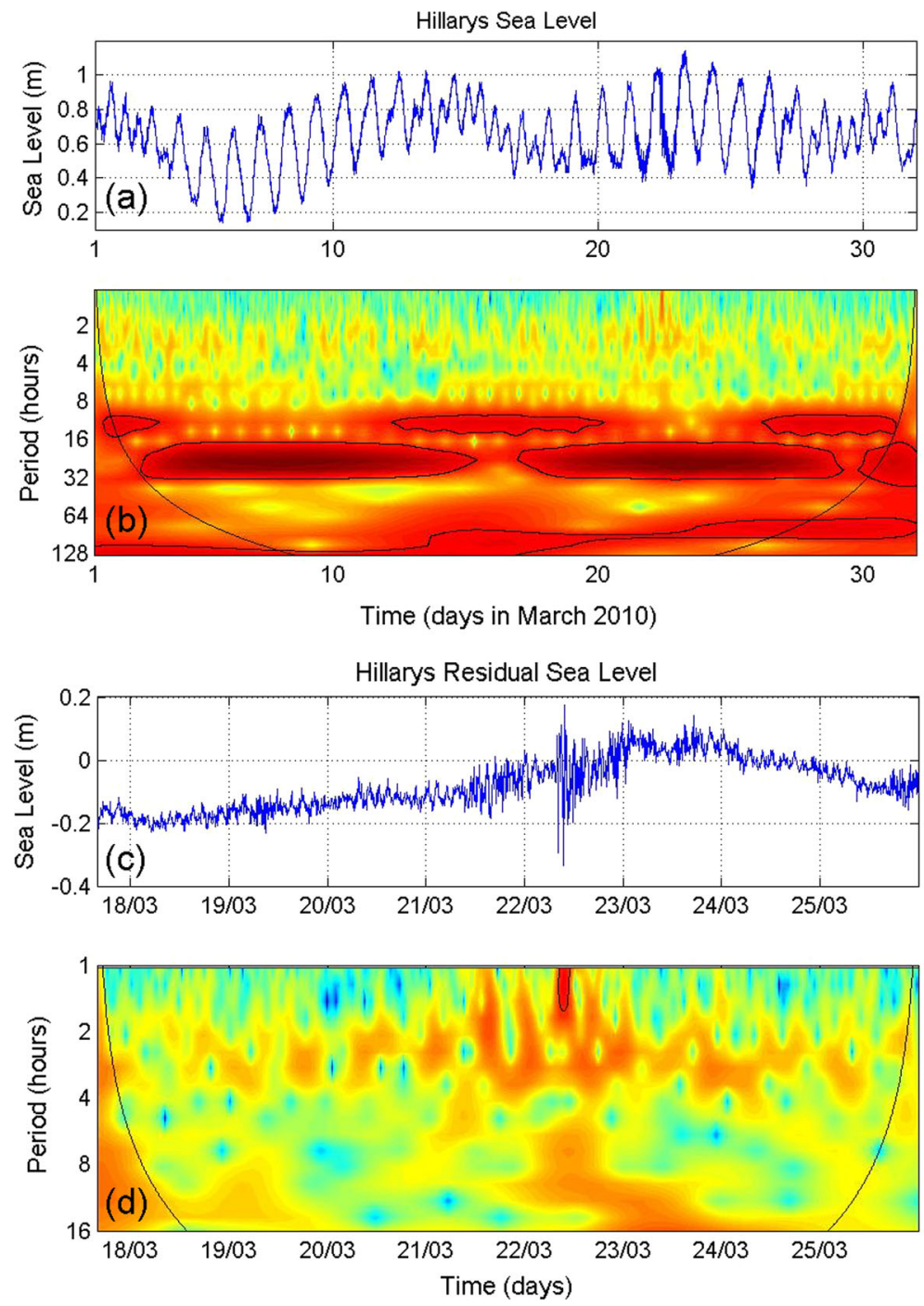

Fig. 8 a Time series of the observed sea level at Hillarys, which had a 6-min sampling interval, for March 2010; b wavelet power spectrum (Morlet) of the observed Hillarys sea level. Contours are in variance units. The solid line indicates the cone of influence; $\mathbf{c}$ the residual time series of the observed sea level at Hillarys for 18-16 March 2010; $\mathbf{d}$ the wavelet power spectrum of the observed residual Hillarys sea level for 18-16 March 2010

pressure of $30 \mathrm{hPa}$ over $36 \mathrm{~h}$ and a minimum of $983 \mathrm{hPa}$ (Fig. 10). Sea surface pressure values $<1,000 \mathrm{hPa}$ are rare in these subtropical systems.

The meteotsunami generated from the low-pressure system produced the highest water level ever recorded at Fremantle, which has a continuous record spanning over 110 years and is the longest sea-level record in the southern hemisphere (Pattiaratchi 2011). The meteotsunami wave height was $0.61 \mathrm{~m}$; however, this was not the highest meteotsunami ever recorded at this site (Fig. 11; Table 1). 


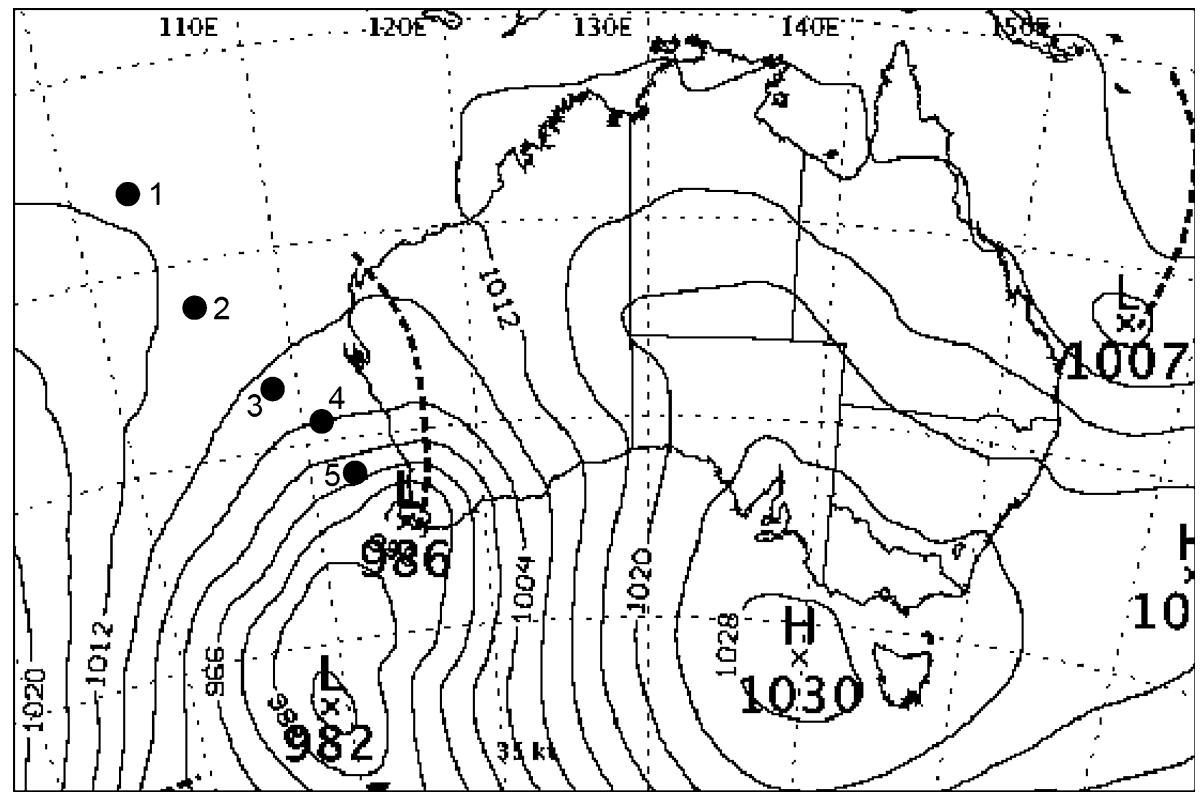

Fig. 9 Mean sea-level pressure distribution at 14:00 on 10 June 2010 showing the location of the lowpressure system off Cape Leeuwin at the time of the highest water level recorded at Fremantle. The locations of the centre of the low-pressure systems for the previous few days are also shown (source http://www.bom. gov.au/australia/charts/archive/index.shtml)

The Fremantle tide record has several components that contribute to sea-level variability: tides, storm surges, and annual and inter-annual variability due to large-scale oceanic changes (Pattiaratchi 2011). The meteotsunami occurred at high tide (Fig. 11) and coincided with the local storm surge; it was also a La Niña year, so the meteotsunami also coincided with a strong Leeuwin current. These factors all contributed to producing the highest water level recorded at Fremantle. In contrast, the corresponding meteotsunamis at Bunbury (wave height of $1.03 \mathrm{~m}$ ) and Busselton (wave height of $1.10 \mathrm{~m}$ ) had the highest wave heights recorded at these stations (Fig. 12; Table 1) and were equivalent to the maximum storm surges recorded at these stations during tropical cyclone Alby in 1978 (Bureau of Meteorology 2012; Haigh et al. 2014).

The meteotsunami was generated during onshore winds. Onshore winds, generated when the front crossed the coast and the wind speed rapidly increased and then decreased over 1-2 $\mathrm{h}$ (as recorded at the meteorological stations) (Fig. 10), most likely caused the meteotsunami. It is also possible that Proudman resonance may have contributed to the generation of the meteotsunami. In a numerical model study, Vilibic (2008) demonstrated that pressure jumps travelling across the shelf, where the depths decrease towards the shoreline, can create conditions for Proudman resonance. However, there is insufficient data to clearly identify the mechanism which was responsible for the generation of the meteotsunami.

\subsubsection{Meteotsunami: 7 January 2013}

Thunderstorms, which affected an area of over $500 \mathrm{~km}$ from Geraldton to Bunbury (Fig. 1), caused the meteotsunami recorded on 7 January 2013. Two pressure jumps of 

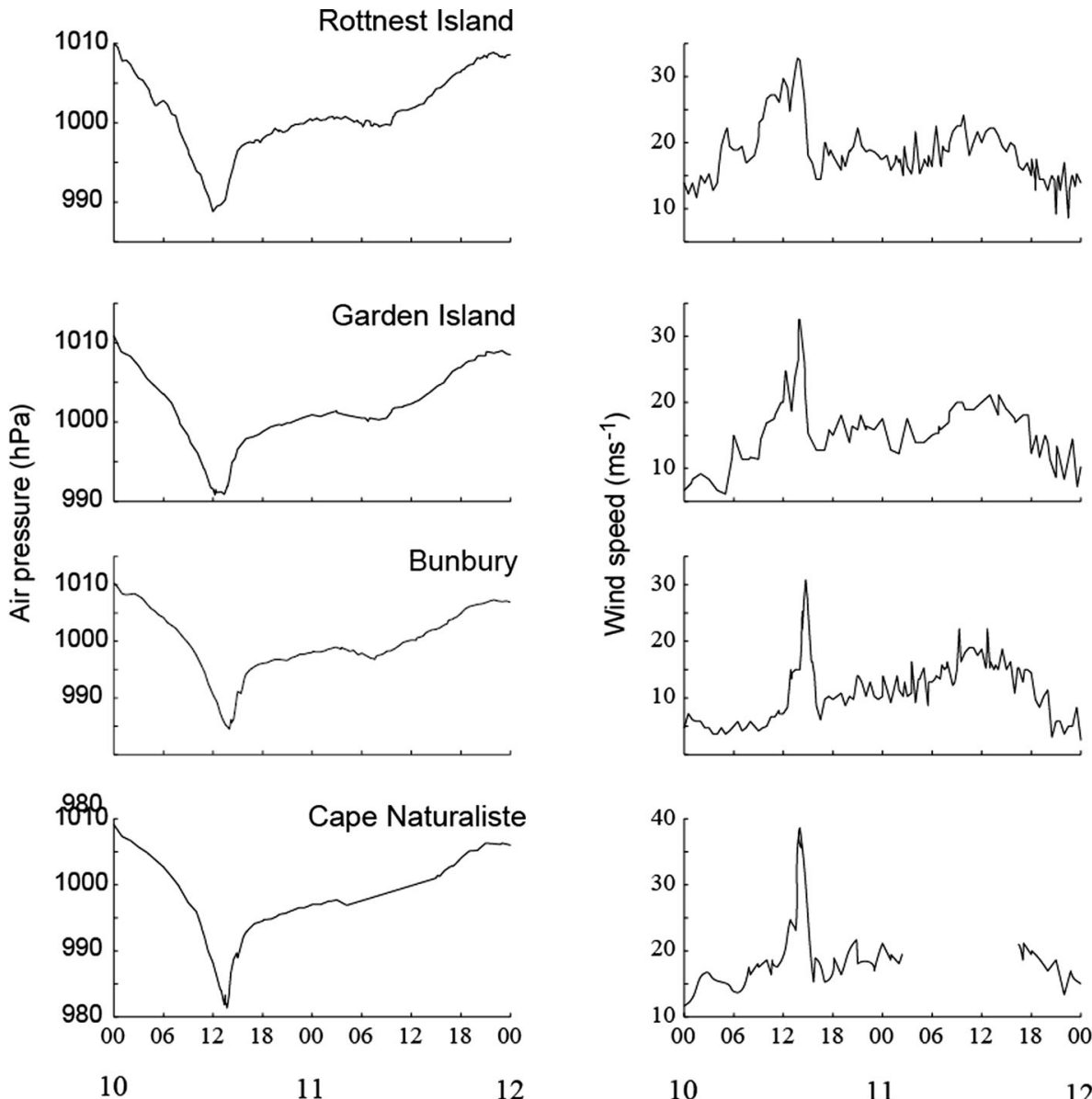

Time (Days in June 2012)

Fig. 10 Time series of air pressure (left panel) and wind speed (right panel) measured at meteorological stations along the Western Australian coast on 10 June 2012 showing the passage of the low-pressure system and associated strong winds and changes in wind direction

$4 \mathrm{hPa}$ were recorded at North Island meteorological station at 0000 and 07:30 (Fig. 13); however, only the first pressure jump generated a meteotsunami at Geraldton at 00:45 (Fig. 14). The initial pressure jump, in the form of a thunderstorm system, moved south and arrived at Rottnest Island at 06:30 (Fig. 13). This pressure jump is reflected in the high rainfall squall band in the rainfall radar image of the Perth region obtained at 06:00 on 7 January (Fig. 15).

The pressure jump speed, estimated using meteorological s data, between North Island and Rottnest Island was $19 \mathrm{~ms}^{-1}$, which increased to $32 \mathrm{~ms}^{-1}$ between Rottnest Island and Bunbury (Fig. 13). If all the meteorological stations were used together with Eq. 2, the mean propagation speed of the pressure jump was $\sim 22 \mathrm{~ms}^{-1}$ and direction $\sim 357^{\circ}$. This indicated that over the propagation distance $(>500 \mathrm{~km})$, the speed of the pressure jumps was not constant. The pressure jumps at each station were associated with peaks in the 


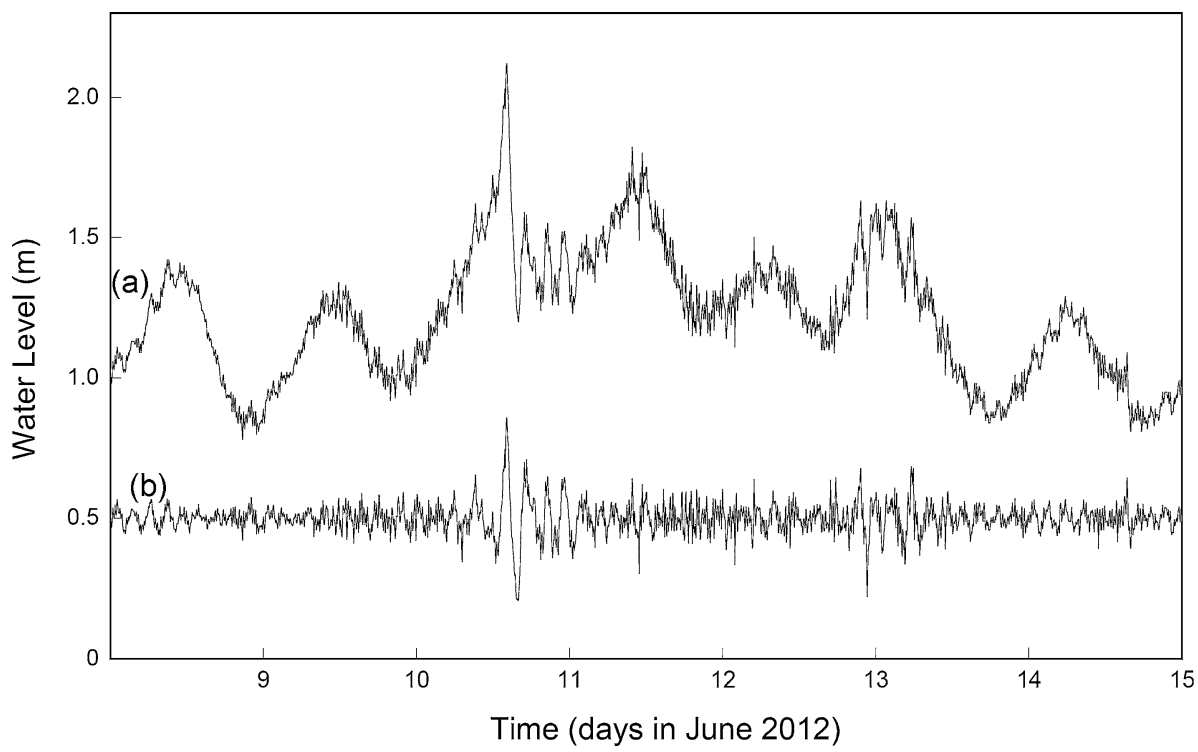

Fig. 11 Time series of the $(a)$ observed and $(b)$ filtered (periods $<6 \mathrm{~h}$ ) water-level records for Fremantle from $8-15$ June 2010

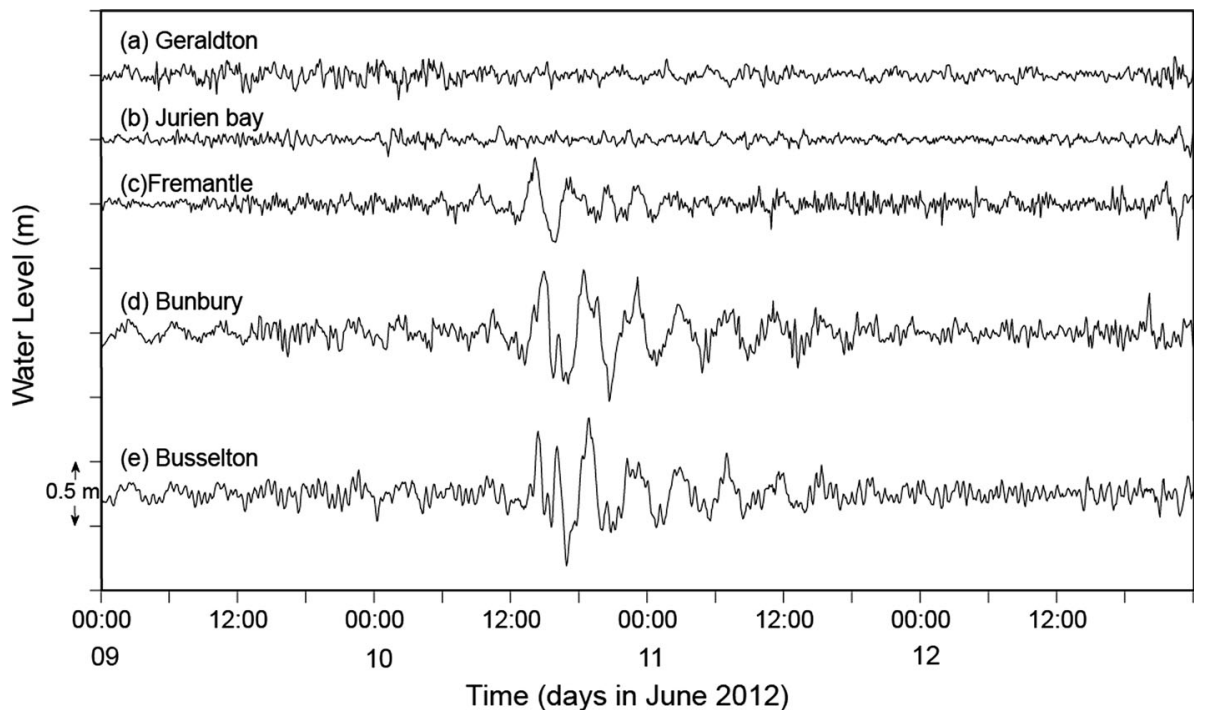

Fig. 12 Time series of the filtered (periods $<6 \mathrm{~h}$ ) water-level records from 9-13 June 2012 for (a) Geraldton; (b) Jurien Bay; (c) Fremantle; (d) Bunbury; and (e) Busselton

wind speed (with wind gusts exceeding $15 \mathrm{~ms}^{-1}$ ) and northerly winds with periods $<1 \mathrm{~h}$ (Fig. 13). The maximum meteotsunami wave height of $0.81 \mathrm{~m}$ was recorded at Geraldton (Table 1), with lower values recorded at Fremantle $(0.48 \mathrm{~m})$, Bunbury $(0.3 \mathrm{~m})$, and Jurien Bay $(0.43 \mathrm{~m})$. The pressure jump speed between Rottnest Island and Bunbury was 

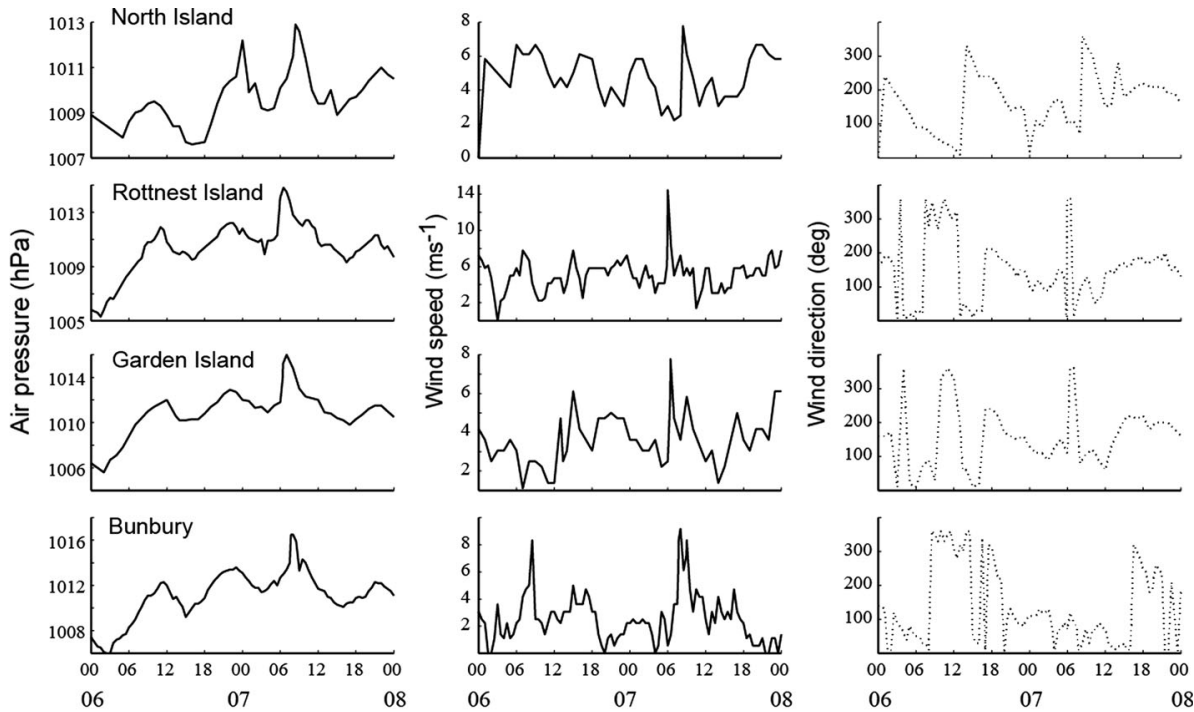

Time (Days in January 2013)

Fig. 13 Time series of air pressure (left panel); wind speed (middle panel); and wind direction (right panel) measured at meteorological stations along the Western Australian coast on 7 January 2013 showing the moving pressure jump and associated changes in wind direction

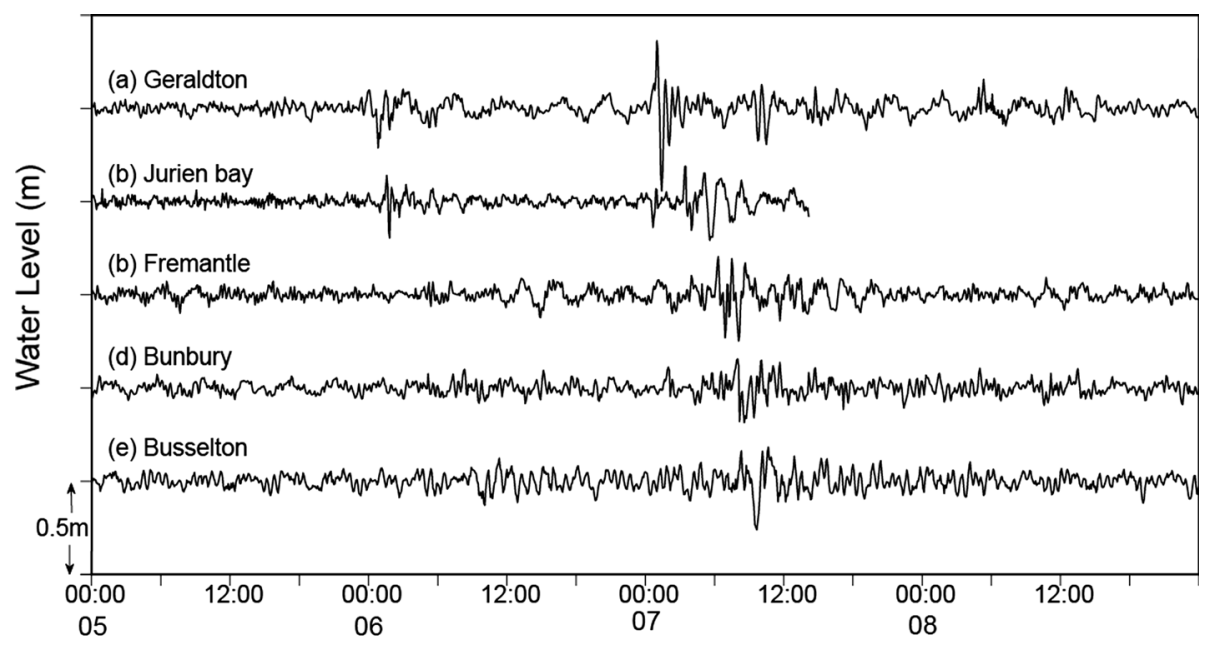

Time (days in January 2013)

Fig. 14 Time series of the filtered (periods $<6 \mathrm{~h}$ ) water-level records from 6-8 January 2013 for (a) Geraldton; (b) Jurien Bay; (c) Fremantle; (d) Bunbury; and (e) Busselton

$32 \mathrm{~ms}^{-1}$, which was similar to the meteotsunami speed between Fremantle and Bunbury of $\sim 30 \mathrm{~ms}^{-1}$, which confirmed that thunderstorms caused the meteotsunami.

The wavelet transform of the Geraldton (Fig. 1) sea-level record, which had a sampling interval of $5 \mathrm{~min}$, shows the dominant energy periods during the meteotsunami (Fig. 16). 


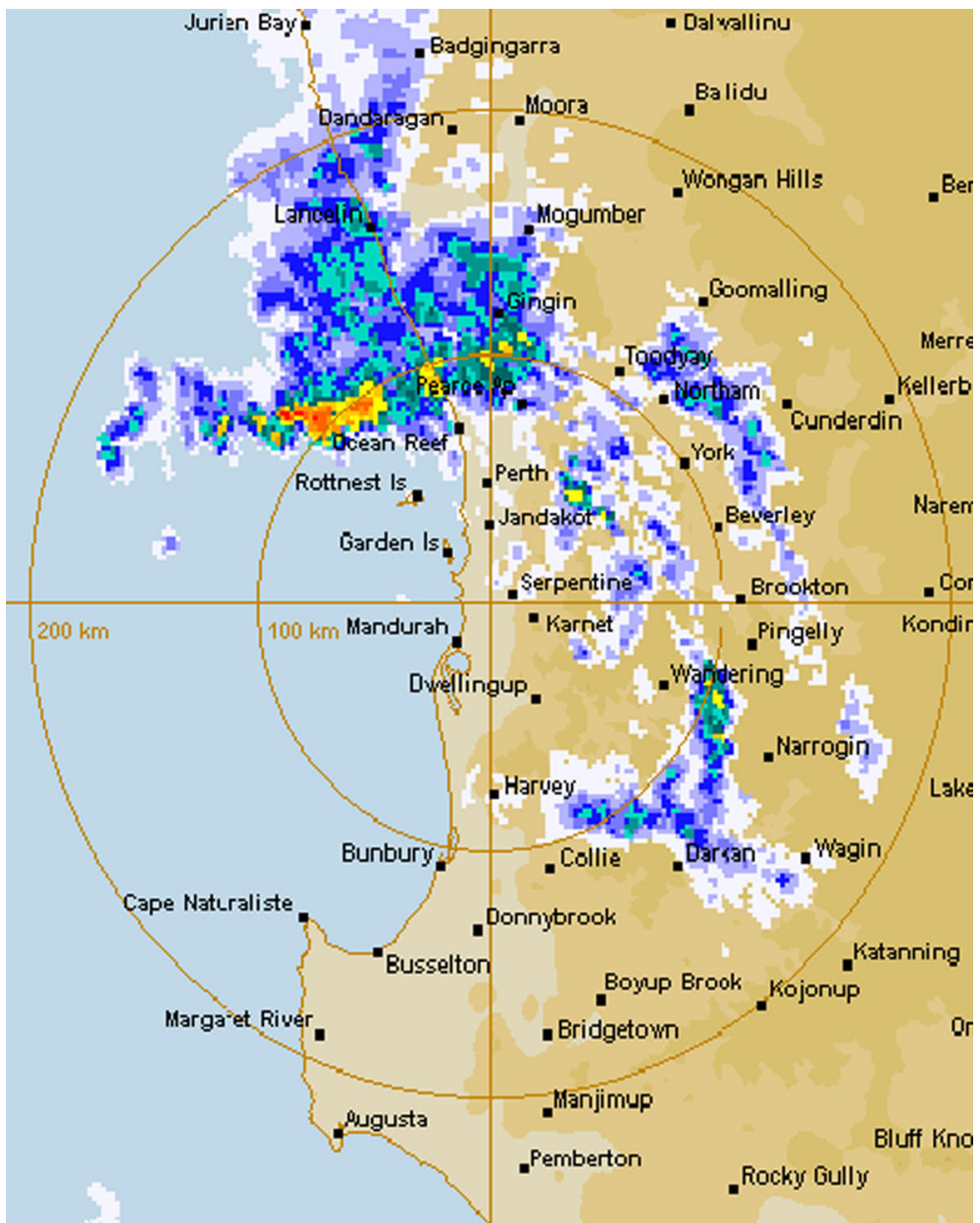

Fig. 15 Radar rainfall image obtained at 06:00 on 7 January 2013 showing the squall line in the Perth region. Warmer colours reflect higher rainfall rates. (Image source: Bureau of Meteorology, Australia)

The time series shows an energy peak of around $4 \mathrm{~h}$, which Pattiaratchi and Wijeratne (2009) identified as the first mode of the shelf resonance (Fig. 16b; see also Figs. 3b, h, 4). Oscillations with periods of 1-2 h were strongly excited during the meteotsunami (Fig. 16b). A smaller meteotsunami with similar periods was identified $24 \mathrm{~h}$ earlier (6 January; Fig. 16b).

\section{Discussion}

This study used data from coastal tide gauges located along the south-west coast of Western Australia to examine the occurrence of meteotsunamis, defined as waves with periods $<6 \mathrm{~h}$ that were related to local weather conditions. The results showed that meteotsunamis often occurred in summer during thunderstorms (especially in the early 
(a)

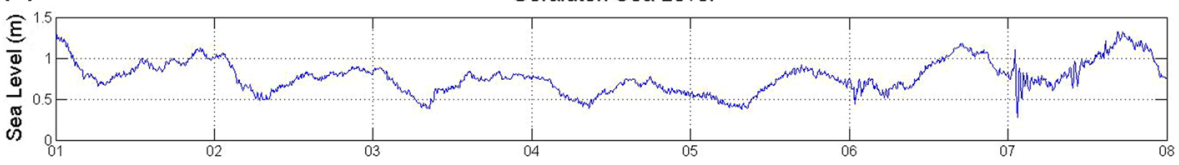

(b)

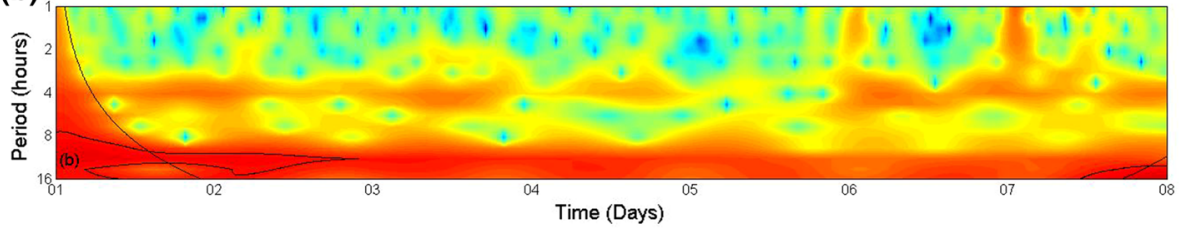

Fig. 16 a Time series of observed sea level at Geraldton at 5-min sampling interval: 1-8 January 2013; b Wavelet power spectrum (Morlet) of observed Geraldton sea level. Contours are in variance units. The solid line indicates the cone of influence

morning, in the late evening, and during supercells) and in winter during the passage of low-pressure systems. Meteotsunamis resulting from the same atmospheric forcing system (e.g. thunderstorms or low-pressure systems) were often identified at meteorological stations up to $500 \mathrm{~km}$ apart. Most of the summer meteotsunamis occurred between midnight and $\sim$ 06:00 or $\sim 15: 00$, and $\sim 20: 00$ and were usually related to the two types of thunderstorms described in Sect. 2. A meteotsunami caused by the passage of a low-pressure system in June 2012 produced the highest water level recorded at Fremantle in 115 years and the highest non-tidal sea-level component at Bunbury and Busselton.

Wave amplification through Proudman resonance (Proudman 1929; Vilibić 2008), by which the speed of an atmospheric disturbance is equal to the shallow-water wave celerity, is one mechanism that causes an increase in the water level at the shoreline. Subsequent oscillations across the continental shelf are generated when the increased water level at the coast attempts to return to its undisturbed position. Under these conditions, an initial increase in the water level occurs, followed by water-level oscillations which may last for several days. Meteotsunamis attributable to Proudman resonance have been observed along the Mallorca shelf, a wide continental shelf similar to that in the study region, where the width is $50 \mathrm{~km}$ and the depth is $50-80 \mathrm{~m}$ (Rabinovich and Monserrat 1998). Proudman resonance has also been attributed to the generation of large meteotsunamis globally (Haslett and Bryant 2009; Rabinovich et al. 2009).

This is the first study to identify meteotsunamis in the study region, and the results showed they occur frequently, particularly during the periods when thunderstorm activity was high. Although meteotsunamis are not catastrophic to the extent of major seismically induced basin-scale events, the wave heights of meteotsunamis examined at many stations in this study were higher than those recorded during the 2004 Indian Ocean tsunami. In other regions, for example, the British Columbia-Washington coast (Canada and USA) and the Bristol Channel (UK), meteotsunamis typically have small wave heights relative to the tidal range (Haslett and Bryant 2009; Thomson et al. 2009). In contrast, the meteotsunamis along the south-west Australian coast, which experiences diurnal tides with a mean tidal range of $\sim 0.5 \mathrm{~m}$ (Pattiaratchi 2011), have wave heights equivalent to, or a factor 2 larger than, the tidal range, similar to those observed in the Mediterranean Sea. 
The events of 10 June 2012, when the highest water level at Fremantle in 115 years was recorded, highlight the force of meteotsunamis. The Fremantle tide gauge recorded a maximum sea level of $2.12 \mathrm{~m}$ (Fig. 11) - $0.14 \mathrm{~m}$ higher than the previous highest sea level recorded at Fremantle of 1.98 m on 16 May 2003 (Bureau of Meteorology 2012). The nontidal or residual component of the water level was estimated to be $1.14 \mathrm{~m}$ (Bureau of Meteorology 2012), and we estimated the meteotsunami had a wave height of $0.61 \mathrm{~m}$ (Table 1; Fig. 11). Thus, $54 \%$ of the non-tidal component of the signal measured at Fremantle for this event, which caused widespread coastal flooding and erosion of beaches due to high water levels, could be attributed to the meteotsunami.

The tide gauge results for Bunbury and Busselton further emphasised the meteotsunami's effect. The non-tidal components of the water levels at Bunbury and Busselton were $1.21 \mathrm{~m}$ and 1.28 , respectively, whilst the meteotsunami wave heights were $1.03 \mathrm{~m}$ and $1.10 \mathrm{~m}$, respectively; thus, $85 \%$ of the non-tidal component of the signal measured at these stations was due to the meteotsunami.

These results highlight the need for a better understanding of, and therefore prediction of, the different processes acting at different temporal scales that contribute to the total sea level. Knowledge of these processes is used for extreme sea-level prediction and coastal planning and design. Currently, the sea-level signal is separated into tidal and non-tidal components, and non-tidal components contain many processes at different temporal scales, including meteotsunamis.

\section{Conclusions}

This study used data from coastal tide gauges and meteorological stations to examine the occurrence, characteristics, and cause of meteotsunamis along the south-west coast of Western Australia. Between 2000 and 2013, the tide gauges frequently recorded the occurrence of meteotsunamis (tsunamis of meteorological origin). The large meteotsunamis (wave heights $>0.4$ ) that occurred during summer coincided with squalls associated with thunderstorms, which generally consisted of moving air pressure disturbances and strong wind gusts. In winter, the passage of a low-pressure system caused a meteotsunami, which produced the highest sea level recorded at Fremantle in 115 years.

A single meteorological event was found to generate several meteotsunamis along the coast, up to $500 \mathrm{~km}$ apart, as the air pressure disturbance propagated over the continental shelf parallel to the coastline; however, the topography and local bathymetry of the continental shelf defined the local sea-level resonance characteristics at each location. The main seiche-period oscillations at each location were associated with the fundamental mode of the continental shelf seiche. Initial wave amplification through Proudman resonance is a mechanism that resulted in meteotsunamis that occurred during summer, with subsequent oscillations (which contributed to the total tsunami oscillations) related to shelf and bay resonance.

Meteotsunamis with amplitudes up to a factor 2 larger than the local tidal range occur frequently along the south-west Australian coast and may contribute to between 50 and $85 \%$ of the non-tidal water signal.

Acknowledgments The authors acknowledge discussions with Ivan Haigh and Matt Eliot on various aspects of the sea-level data presented here. The weather records and meteorological data for this study were obtained from the Australian Government Bureau of Meteorology. We would like to thank Tony Lamberto 
and Reena Lowry (Department of Transport, Government of Western Australia) for facilitating the provision of the tide data and Ruth Gongora-Mesas for help in the preparing of the final manuscript.

Open Access This article is distributed under the terms of the Creative Commons Attribution License which permits any use, distribution, and reproduction in any medium, provided the original author(s) and the source are credited.

\section{References}

Bureau of Meteorology (2012) A significant winter wind and storm surge event in southwest Western Australia in early June 2012, special climate statement 40

Burling MC, Pattiaratchi CB, Ivey GN (2003) The tidal regime of Shark Bay, Western Australia. Estuar Coast Shelf Sci 57(5-6):725-735

Candela J, Mazzola S, Sammari C, Limeburner R, Lozano CJ, Patti B, Bonnano A (1999) The "mad sea" phenomenon in the Strait of Sicily. J Phys Oceanogr 29(9):2210-2231

Cho K-H, Choi J-Y, Park K-S, Hyun S-K, Oh Y, Park J-Y (2013) A synoptic study on tsunami-like sea level oscillations along the west coast of Korea using an unstructured-grid ocean model. In Conley DC, Masselink G, Russell PE, O'Hare TJ (eds) Proceedings of the twelfth international coastal symposium, vol. 1, Journal of Coastal Research special issue no. 65, pp. 678-683, Coastal Processes Research Group, School of Marine Science and Engineering, Plymouth University, Plymouth

Courtney J, Middelmann M (2005) Meteorological hazards. In: Natural hazard risk in Perth, Western Australia: comprehensive report, compiled by T. Jones, M. Middelmann and N. Corby, pp. 21-62, Geoscience Australia, Canberra

Defant A (1961) Physical oceanography. Pergamon Press, New York

Drago A (2008) Numerical modeling of coastal seiches in Malta. Phys Chem Earth 33:260-275

Garcies M, Gomis D, Monserrat S (1996) Pressure-forced seiches of large amplitude in inlets of the Balearic Islands: 2. Observational study. J Geophys Res Oceans 101(C3):6453-6467

Gomis D, Monserrat S, Tintoré J (1993) Pressure-forced seiches of large amplitude in inlets of the Balearic Islands. J Geophys Res Oceans 98(C8): 14,437-14,445

Greenspan HP (1956) The generation of edge waves by moving pressure distributions. J Fluid Mech 1(6):574-592

Haigh ID, Wijeratne EMS, MacPherson LR, Pattiaratchi CB, Mason MS, Crompton RP, George S (2014) Estimating present day extreme water level exceedance probabilities around the coastline of Australia: tides, extra-tropical storm surges and mean sea level. Clim Dyn. doi:10.1007/s00382-012-1652-1

Haslett SK, Bryant EA (2009) Meteorological tsunamis in southern Britain: an historical review. Geogr Rev 99(2):146-163

Heath RA (1982) Generation of 2-3 h oscillations on the east coast of New Zealand. NZ J Mar Freshwat Res 16:111-117

Hibiya T, Kajiura K (1982) Origin of the Abiki phenomenon (a kind of seiche) in Nagasaki Bay. J Oceanogr Soc Jpn 38(3): 172-182

Ilich K (2006) Origin of continental shelf seiches, Fremantle, Western Australia, honours thesis, School of Environmental Systems Engineering, the Univ. of Western Australia, Perth, Western Australia

Jansa A, Monserrat S, Gomis D (2007) The rissaga of 15 June 2006 in Ciutadella (Menorca), a meteorological tsunami. Adv Geosci 12:1-4

Kuleshov Y, de Hoedt G, Wright W, Brewster A (2002) Thunderstorm distribution and frequency in Australia. Aust Meteorol Mag 51(3):145-154

Monserrat S, Ibbetson A, Thorpe AJ (1991) Atmospheric gravity waves and the 'rissaga' phenomenon. Q J R Meteorol Soc 117(449):553-570

Monserrat S, Vilibić I, Rabinovich AB (2006) Meteotsunamis: atmospherically induced destructive ocean waves in the tsunami frequency band. Nat Hazards Earth Syst Sci 6(6):1035-1051

Nudelman I, Smith RK, Reeder MJ (2010) A climatology of pressure jumps around the Gulf of Carpentaria. Aust Meteorol Oceanogr J 60(2):91-101

O'Callaghan J, Pattiaratchi CB, Hamilton D (2010) The role of intratidal oscillations in sediment resuspension in a diurnal, partially mixed estuary. J Geophys Res Oceans 115:C07018. doi:10.1029/ 2009JC005760

Orlić M (1980) About a possible occurrence of the Proudman resonance in the Adriatic. Thalassia Jugoslavica 16(1):79-88 
Orlic M, Belusic D, Janekovic I, Pasaric M (2010) Fresh evidence relating the great Adriatic surge of 21 June 1978 to mesoscale atmospheric forcing. J Geophys Res 115:C06011. doi:10.1029/2009JC005777

Pasquet S et al (2013) A survey of strong high-frequency sea level oscillations along the US East Coast between 2006 and 2011. Nat Hazards Earth Syst Sci 13:473-482

Pattiaratchi CB (2011) Coastal tide gauge observations: dynamic processes present in the Fremantle record. In: Schiller A, Brassington GB (eds) Operational oceanography in the 21 st century. Springer, Dordrecht, pp 185-202

Pattiaratchi CB, Eliot M (2009) Sea level variability in south-west Australia: from hours to decades. In: J. McKee Smith (ed) Coastal engineering: proceedings of the thirty-first international coastal engineering conference. World Scientific Publishing Co., Singapore, pp. 1186-1198

Pattiaratchi CB, Wijeratne EMS (2009) Tide gauge observations of the 2004-2007 Indian Ocean tsunamis from Sri Lanka and Western Australia. Pure Appl Geophys 166(1-2):233-258

Pawlowicz R, Beardsley B, Lentz S (2002) Classical tidal harmonic analysis including error estimates in MATLAB using T_TIDE. Comput Geosci 28(8):929-937

Proudman J (1929) The effects on the sea of changes in atmospheric pressure. Geophys J Int 2(4):197-209

Pugh DT (1987) Tides, surges and mean sea-level: a handbook for engineers and scientists. Wiley, Chichester

Rabinovich AB (2009) Seiches and harbour oscillations. In: Kim YC (ed) Handbook of coastal and ocean engineering. World Scientific Publishing Co., Singapore, pp 193-236

Rabinovich AB, Monserrat S (1996) Meteorological tsunamis near the Balearic and Kuril Islands: descriptive and statistical analysis. Nat Hazards 13(1):55-90

Rabinovich AB, Monserrat S (1998) Generation of meteorological tsunamis (large amplitude seiches) near the Balearic and Kuril Islands. Nat Hazards 18(1):27-55

Rabinovich AB, Vilibić I, Tinti S (2009) Meteorological tsunamis: atmospherically induced destructive ocean waves in the tsunami frequency band. Phys Chem Earth 34(17-18):891-893

Renault L, Vizoso G, Jansa A, Wilkin J, Tintor J (2011) Toward the predictability of meteo-tsunamis in the Balearic Sea using coupled atmosphere-ocean modeling. Geophys Res Lett 38:L10601. doi:10.1029/ 2011GL047361

Šepić J, Vilibić I, Belušić D (2009) Source of the 2007 Ist meteotsunami (Adriatic Sea). J Geophys Res 114:C03016. doi:10.1029/2008JC005092

Tappin D, Sibley A, Horsburgh K, Daubord C, Cox D, Long D (2013) The English Channel tsunami of 27 June 2011-a probable meteorological source. Weather. Published online May 2013. doi: 10.1002/wea. 2061

Thomson RE, Rabinovich AB, Fine IV, Sinnott DC, McCarthy A, Sutherland NAS, Neil LK (2009) Meteorological tsunamis on the coasts of British Columbia and Washington. Phys Chem Earth 34(17-18):971-988

Thotagamuwage DT, Pattiaratchi CB (2011) Observations of infra-gravity period oscillations and their forcing in Western Australia. In Coasts and ports 2011: diverse and developing: proceedings of the twentieth australasian coastal and ocean engineering conference and the thirteenth Australasian port and harbour conference, pp. 725-730, Engineers Australia, Barton

Torrence C, Compo GP (1998) A practical guide to wavelet analysis. Bull Am Meteorol Soc 79(1):61-78

Verspecht F, Pattiaratchi CB (2010) On the significance of wind event frequency for particulate resuspension and light attenuation in coastal waters. Cont Shelf Res 30(18):1971-1982

Vilibić I (2008) Numerical simulations of the Proudman resonance. Cont Shelf Res 28(4-5):574-581

Vilibić I, Šepić J (2009) Destructive meteotsunamis along the eastern Adriatic coast: overview. Phys Chem Earth 34(17-18):904-917

Vilibić I, Monserrat S, Rabinovich AB, Mihanović H (2008) Numerical modelling of the destructive meteotsunami of 15 June, 2006 on the coast of the Balearic Islands. Pure Appl Geophys 165(11-12):2169-2195

Wijeratne EMS, Woodworth PL, Pugh DT (2010) Meteorological and internal wave forcing of seiches along the Sri Lanka coast. J Geophys Res 115:C03014. doi:10.1029/2009JC005673 